\title{
Konsumsi Berita Insidental di Media Sosial pada Generasi Dewasa
}

\author{
Era Realita ${ }^{1}$, Usman Setiadi ${ }^{2}$ \\ ${ }^{1}$ Universitas Diponegoro \\ ${ }^{2}$ Universitas Negeri Semarang \\ E-mail: realitaera13@gmail.com
}

\begin{abstract}
Abstrak
Berita insidental merupakan hasil olah sistem algoritma yang diterapkan oleh perusahaan media. Penelitian ini menunjukkan bagaimana latar belakang pengguna media sosial mempengaruhi konsumsi berita insidental. Metode yang digunakan adalah kajian pustaka dan wawancara singkat pada 20 orang dewasa yang bekerja di berbagai sektor dengan rentang usia 23-25 tahun. Hasil menunjukkan bahwa pekerjaan dan usia mempengaruhi pemilihan konten informasi. Konten-konten tersebut dipilih untuk menunjang kebutuhan informasi mereka. Menanggapi munculnya berita insidental, beberapa narasumber mengaku tidak peduli pada asal-usul berita tersebut. Selama konten yang dimuat menarik minat mereka, tidak ada yang perlu dipertanyakan. mereka juga beranggapan bahwa berita insidental dapat menjadi jalan pintas yang efektif untuk mencapai sumber asli berita. Walaupun demikian, dalam mengkonsumsi berita insidental sebaiknya kita tetap waspada dan berhati-hati, karena tidak semua sumber berita itu akurat dan dari teori kemunculan berita insidental yang memanfaatkan rekam jejak digital, dapat mengacam data pribadi kita.
\end{abstract}

Kata Kunci: Berita insidental, Media sosial, Konsumsi berita online

\begin{abstract}
Incidental news is the result of an algorithm system implemented by media companies. This study shows how background of the social media users influence incidental news consumtion. The method used is literatures review and short interviews with 20 adults working in various sectors with an age range of 23-25 years. The results show that background of profession and age are influencing the choose of news content. Responding to the emergence of incidental news, several respondents did not care about the origin of the news. As long as the content loaded interests them, there is nothing to question. they also think that incidental news can be an effective shortcut to reach the original source of the news. It can be concluded that adults generally feel helped in the news search process with incidental news. Nevertheless, in consuming incidental news, we should remain vigilant and careful because not all news sources are accurate and from the theory of incidental news emergence that utilizes digital track records that can threaten our personal data.
\end{abstract}

Keywords: Incidental news, Social media, Online news consumption 


\section{PENDAHULUAN}

Penelitian ini membahas tentang bagaimana minat dan latar belakang pengguna media sosial terhadap keberadaan berita insidental di akun media sosial mereka. Kedua hal tersebut kemudian akan dikaitkan dengan keputusan dalam konsumsi berita insidental. Menurut survei yang dilakukan oleh Asosiasi Penyelenggara Jaringan Internet Indonesia (APJII) pada tahun 2016, disebutkan bahwa lebih dari setengah penduduk Indonesia, yaitu sebanyak 132,7 juta dari total 256,2 juta orang telah terhubung ke internet dan memiliki media sosial (medsos). Media Sosial menyediakan ruang baru yang penting bagi informasi warga dan kegiatan partisipatif. Studi yang ada menunjukkan bahwa penggunaan media sosial berhubungan positif untuk partisipasi politik dan bahwa hubungan ini telah menjadi lebih kuat dari waktu ke waktu (Boulianne, 2018). Media sosial menyusun lingkungan jaringan di mana item berita dapat lebih mudah terlihat dan menarik perhatian orang. Bahkan jika pengguna tidak secara aktif mencari suatu berita, ketika teman mereka memposting, menyukai, dan berbagi berita dan komentar, kemungkinan besar pengguna menemukan aktivitas tersebut di umpan berita dan/atau melalui pemberitahuan situs dan email. Alasan kedua adalah sifat sosial dari terpaan berita di media sosial. Rekomendasi sosial, seperti postingan yang direkomendasikan oleh koneksi online dan berapa kali postingan dibagikan dan disukai, berfungsi sebagai heuristik dari kepentingan dan popularitas konten. Penelitian menunjukkan bahwa rekomendasi sosial menimbulkan rasa ingin tahu tentang item berita, memengaruhi keputusan orang tentang konten apa yang akan dikonsumsi, dan memfasilitasi pencarian informasi (Anspach, 2017; Turcotte, York, Irving, Scholl, \& Pingree, 2015; Xu, 2013). Karakteristik ini menunjukkan bahwa media sosial meningkatkan paparan berita insidental dan tindakan selanjutnya relatif terhadap saluran lain seperti email, pesan instan, dan iklan.

Mayoritas pengguna medsos adalah generasi muda atau remaja, sedangkan untuk usia dewasa hingga lansia lebih sedikit jumlahnya karena faktor keterbatasan fisik dan waktu luang. Selain tingkat kedewasaan, faktor lingkungan sekitar juga menjadi pendorong perilaku konsumsi berita online. Pola mengakses berita dipengaruhi oleh latar belakang dan kondisi lingkungan (Rusadi, 2014). Mengakses berita online selain membutuhkan jaringan internet juga membutuhkan media perantara. Media yang populer digunakan oleh masyarakat antara lain adalah ponsel pintar dan Personal Computer seperti Tab atau laptop. Menurut penelitian dari Hatama, dkk (2021) durasi dan frekuensi penggunaan gawai dapat mempengaruhi konsumsi media sosial. Semakin sering seseorang menggunakan gawai maka kemungkinan mengakses media sosial juga semakin tinggi.

Pertumbuhan jumlah pengguna medsos ini dipengaruhi oleh perkembangan teknologi infomasi dan komunikasi serta perkembangan ideologi dunia tentang tatanan masyarakat demokrasi. Dalam tatanan masyarakat demokrasi setiap individu bahkan setiap komunitas sadar akan haknya untuk menunjukkkan eksistensinya. Lebih dari itu mereka punya ambisi untuk ikut memiliki terhadap kondisi yang terjadi. Faktor-faktor ini kemudian menjadi alasan bagi beberapa negara untuk mempermudah proses produksi dan distribusi informasi. Kemudahan dalam mengakses dan menyebarkan informasi ini juga dapat memengaruhi 
konsumsi berita online. Perilaku konsumsi berita kini mengalami perubahan yang sangat cepat. Pola perilaku mulai bergeser dari yang semula membaca berita cetak (surat kabar dan majalah) dari publikasi dan jurnalisme profesional ke akses informasi yang lebih kompleks dimana setiap orang tidak hanya mengonsumsi saja namun juga dapat menjadi jurnalis atau bahkan penerbit. Bahkan beberapa perusahaan media konvensional yang memiliki reputasi baik di masyarakat, dan hingga saat ini masih menjadi penyuplai sebagian besar berita yang dikonsumsi masyarakat, juga mulai merambah media sosial dan agregator (David Domingo, Pere Masip \& Irene Costera Meijer, 2015)

Menurut Holton, Media sosial memberikan kemudahan akses ke situs berita serta kesempatan untuk terlibat dalam proses produksi dan penyebaran berita, melalui fitur komentar, berbagi dan publikasi online (Holton, 2015). Orang-orang yang terpapar biasanya sebagian besar berdasarkan minat atau perilaku orang-orang yang terhubung dengan mereka melalui media ini (Karlsen 2015; Thorson \& Wells, 2015). Selain itu, berita-berita saat ini juga menjadi lebih terintegrasi ke semua jenis aktivitas, situs website, dan genre (Costera Meijer \& Kormelink, 2014). Sosial media dapat menjadi tempat yang cocok untuk memasang 'iklan' yang menarik pembaca. Hal-hal ini kemudian memicu munculnya berita insidental yang menggiring pengguna medsos untuk masuk ke situs website berita. Hal ini merupakan bagian dari hasil kerja sistem algoritma pada media sosial.

Faktanya semakin masif penggunaan media sosial online menjadikan media sosial cetak kian tereliminir. Hal ini sudah menjadi konsekuensi logis dengan ditandai pengurangan upah dan PHK karyawan kalau tidak tutup produksi sama sekali. Konsumen berita yang tetap haus akan informasi terkini mau tidak mau beralih ke media sosial online yang akselerasinya lebih cepat. Mereka juga harus menjadi pengguna media sosial online bukan sekadar penikmat karena harus membeli perangkatnya berupa HP, kuota internet, atau pemasangan WIFI. Dengan perangkat itu mereka bisa disebut sebagai pengguna media sosial online yang standar. Suciati dan Fauziah dalam hasil penelitiannya menegaskan bahwa telah terjadinya pergeseran pada konsumsi berita di masyarakat, media sosial menjadi gatekeeping baru serta beberapa nilai baru dalam memahami fenomena konsumsi berita oleh publik. Nilai-nilai tersebut meliputi peran beritan sensasional sebagai click bait untuk mengundang audiens (Suciati \& Fauziah, 2020).

Walaupun mayoritas masyarakat dapat dengan lincah menggunakan internet, masih ada beberapa orang yang gagap teknologi. Kita sebut saja generasi lansia, minat dan waktu untuk belajar teknologi dan internet sudah sangat minim sehingga menjadikannya tertinggal. Selain itu, kondisi daerah yang berbeda sehingga menyulitkan transmisi jaringan sinyal internet, seperti di daerah terpencil dan pegunungan. Dalam artikelnya, Rusadi menggunakan istilah generasi digital native untuk orang-orang yang memiliki tingkat literasi digital tinggi, hidup bergantung pada teknologi digital, serta memiliki perspektif atau pola pikir lebih besar melalui media online untuk kehidupannya. Walupun begitu, mereka tetap menggunakan televisi dan sumber berita konvensional lainnya sebagai sumber sekunder dalam mencari berita. Disebutkan bahwa pola konsumsi berita bermula dari sosial media, dalam konteks penelitian Rusadi adalah Twitter sebagai microblog untuk mengetahui topik terkini atau biasa disebut dengan istilah trending topic. Kemudian berlanjut pada penelusuran lebih lanjut informasi ke sumber asal atau portal pembuat berita tersebut. Selanjutnya jika diperlukan, 
orang-orang akan menonton televisi untuk menyaksikan dramatisasi visual atau programprogram dialog terkait berita yang sebelumnya mereka baca. Dari sini dapat kita lihat sebenarnya proses peralihan dari konsumsi berita konvensional ke berita online masih belum sepenuhnya. Walaupun mengonsumsi berita online, orang-orang tetap membutuhkan sumber berita konvensional sebagai pelengkap.

Orang-orang mendengarkan program berita tertentu atau membeli surat kabar terkenal karena perasaan percaya pada sumber berita yang mereka anggap sudah familiar di kehidupan mereka. Berita yang mereka konsumsi juga bergantung pada kebiasaan perusahaan media tersebut. Pada medsos, pengguna memilih berita dari berbagai sumber yang disarankan oleh algoritme jaringan, teman atau pengikut (Messing \& Westwood, 2014). Jadi, berita muncul sebagai akibat dari paparan insidental atau atas rekomendasi orang lain yang diketahui dan diikuti oleh pengguna. Peran opinion leader di medsos telah dijelaskan dalam beberapa penelitian sebelumnya. Teman di jejaring sosial memengaruhi algoritma distribusi berita setelah menggunakan fitur "disukai", "dibagikan", atau "direkomendasikan" (Hermida dkk, 2012). Di Twitter beberapa orang yang dipercaya dan sering diminta pendapatnya, ternyata sangat memengaruhi konsumsi berita orang lain (Choi, 2015). Opinion Leader dan jaringan interpersonal adalah dua faktor yang sama pentingnya dalam arus komunikasi di medsos (Karlsen, 2015).

Ali dalam penelitiannya mengatakan jika media sosial memiliki peran yang penting karena fiturnya yang interaktif sehingga memudahkan audiens untuk menerima dan mengirim informasi ke pengguna lainnya. Namun, dengan memanfaatkan kekuatan media sosial tentunya hal tersebut bergantung kepada isi pesan yang akan disebarkannya. Apakah isi pesan tersebut akan membangkitkan motivasi audiens untuk membagikannya kepada audiens lainnya atau tidak. Beberapa penelitian sebelumnya telah meneliti mengenai hubungan antara atribut pesan media sosial dan peningkatan terhadap engagement media sosial dalam konteks darurat kesehatan masyarakat. Hasilnya menunjukkan bahwa komunikasi kesehatan pada saat krisis kesehatan terjadi sangat menyimpang dari komunikasi kesehatan a pesan-pesan media sensasionalis yang membangkitkan rasa takut akan memengaruhi persepsi audiens tentang risiko. Pernyataan tersebut juga didukung oleh penelitian sebelumnya bahwa emosi yang terangsang adalah penentu signifikan persepsi risiko. Jika peran emosional negatif dalam membentuk sebuah persepsi risiko sudah terbukti sebagai faktor yang sangat berpengaruh secara tradisional (yang seharusnya) dalam berbagai aspek, termasuk intensitas (Ali et al., 2019).

Sebenarnyanya dalam melakukan proses pencarian berita di media sosial, segala aktifitas pencarian terekam dan dapat dimanfaatkan. Seperti yang dinyatakan oleh (Valeriani dan Vaccari, 2016) bahwa proses distribusi berita dapat dianggap sebagai produk sampingan dari kegiatan lain. Kegitaan lain yang dimaksud adalah suatu jembatan menuju suatu konten yang muncul dari kebiasaan penggunaan media dan akses ke saluran atau konten tertentu. Meijer menambahkan bahwa hal ini juga menjadi bagian dari apa yang disebut sebagai "pengecekan ruang lingkup". Dalam konteks media sosial, di mana gambar kucing, pesta, selebriti, dan pembaruan berorientasi sosial secara tidak teratur tetapi terus menerus bercampur dengan berita, kemungkinan mendapatkan berita tersebut menjadi jauh lebih besar (Meijer \& Kormelink, 2014). 
Dalam penelitian milik Pablo J. Boczkowski dijelaskan bahwa kemunculan berita insidental sendiri sebenarnya sudah muncul bahkan sebelum adanya media sosial. Contoh adalah ketika kita sedang antre di kasir dan tidak sengaja membaca headline berita di koran yang ada di rak dan karena merasa tertarik kemudian membeli koran tersebut (Boczkowski, 2018). Penelitian selanjutya milik Oeldorf-Hirsch mencoba secara rinci untuk menjelaskan konsep paparan berita insidental sebagai pengguna yang terpapar berita ketika mereka tidak secara aktif mencari berita tersebut. Dalam penelitian Oeldorf dijelaskan bahwa pengguna media sosial yang terlibat dengan konten berita di Facebook dan Twitter akan memiliki efek terhadap cara mereka memproses konten tersebut. Ketika pengguna melihat konten berita di media sosial, pengguna akan bereaksi terhadap konten tersebut, baik melalui engagement fitur di media sosial atau juga secara kognitif terlibat. Hal tersebut juga terlepas dari cara mereka mendapatkan konten berita tersebut, apakah dengan mencari sendiri atau menemukannya secara pasif terpapar (insidental). Lebih lanjut lagi, hasil penelitiannya menemukan jika pengguna yang menemukan berita secara insidental, mereka akan memiliki tingkat keterlibatan yang serupa dengan pengguna yang aktif mencari berita. Dalam konteks media sosial sendiri, pengguna yang terpapar berita di media sosial memiliki tujuan lain saat menggunakan media sosial tersebut. Jadi, incidental news exposure menjadi peran yang penting karena pengguna tidak bisa mengonsumsi semua berita yang ada di media, baik online atau konvensional. Oleh karenanya, pengguna yang terkena incidental news exposure akan secara positif memiliki keterkaitan dengan pengetahuan terkini dan juga keterlibatan dengan konten berita tersebut (Oeldorf-Hirsch, 2017).

\section{METODOLOGI}

Penelitian ini menggunakan teknik pengumpulan data melalui wawancara dengan narasumber dan kajian pustaka dari penelitian-penelitian sebelumnya terkait konsumsi berita insidental. Proses wawancara dilakukan terhadap orang dewasa yang telah bekerja di berbagai sektor. Tujuan input data dari wawancara adalah untuk menambah kedalaman proses mengkaji fenomena ini serta mencari keberagaman yang mungkin timbul. Pertanyaan yang diajukan pada sesi wawancara berjumlah 10 pertanyaan yang merepresentasikan dua pertanyaan utama dari penelitian ini, yaitu tentang bagaimana pengetahuan dan minat orang dewasa dalam mengonsumsi berita insidental di media sosial. Narasumber berjumlah 20 orang dewasa dengan rentang usia 23-25 tahun. Narasumber penelitian berasal dari rentang usia dewasa tersebut semuanya sudah bekerja di sektor-sektor yang berbeda. Meliputi 10 orang bekerja di sektor pendidikan, 4 orang wiraswata, 3 orang ojek online, 2 pegawai bank swasta dan seorang tenaga medis. Media Sosial kini telah menjadi bagian dari kehidupan masyarakat. Hampir semua orang mengenal sosial media dan menjadi pengguna aktif.

Alasan pemilihan kriteria narasumber tersebut terinspirasi dari hasil studi milik Freeman yang menyatakan bahwa orang dewasa yang tergolong dalam generasi milineal memilih internet sebagai sumber utama dalam mencari berita (Freeman, 2013). Pernyataan ini merupakan dukungan terhadap penelitian sebelumnya oleh Asosiasi Surat Kabar Dunia yang berpendapat serupa. Freeman menggunakan narasumber dengan rentang usia 18-24 tahun. Semua narasumbermerupakan pelanggan situs berita online di Malaysia dan setengah dari narasumbermerupakan pembaca regular dari berita online. Pada rentang usia 21-24 tahun, 
ditemukan fakta bahwa kelompok usia ini membaca berita online lebih sering dibandingkan pada kelompok usia 18-20 tahun. Kelompok usia yang lebih dewasa menunjukkan minat lebih tinggi pada konten berita online. Mereka mengkonsumsi berita online dari hampir seluruh media. Konsumsi berita online berorientasi pada media digital, terutama website internet dan media sosial. Hal ini menunjukkan bahwa rasa haus akan berita terkini masih tinggi. Minat konsumsi yang tinggi ini ternyata juga dipengaruhi oleh tingkat usia dan kedewasaan seseorang.

\section{HASIL DAN PEMBAHASAN}

Penelitian ini berangkat dari topik tentang berita insidental yang muncul di media sosial. Saat ini perusahaan media atau penerbitan telah beralih dari media cetak ke media digital sebagai upaya bertahan dalam arus digitalisasi. Orang-orang kini dapat mengakses berita dari gawai mereka kapan saja dan dimana saja. Istilahnya adalah informasi ada di ujung jari. Kemudahan penyebaran informasi didukung dengan kemajuan sistem pada media sosial, dimana kini disediakan fasilitas untuk menyebarkan konten berita dengan sangat cepat dan efektif yaitu dengan sekali klik, pengguna dapat berpindah ke halaman website pembuat konten berita tersebut. Berdasarkan wawancara terhadap 20 orang narasumber atau sumber kunci, semuanya menyatakan paling sering aktif di media sosial Instagram. Hal ini kemudian yang menjadi pertimbangan peneliti untuk menggunakan media sosial Instagram sebagai subyek dalam membahas kemunculan berita insidental. Semua narasumber mengaku bahwa mereka telah menyadari kemunculan berita insidental di saat mereka mengakses media sosial. Namun, hanya 8 orang yang paham sistem algoritma dari kemunculan berita insidental. Sisanya lebih memilih tidak memperdulikan dari mana asal usul dari berita insidental tersebut.

Hasil lainnya yang diperoleh adalah fakta bahwa latar belakang pendidikan dan profesi seseorang dapat mempengaruhi jenis konten berita yang diminatinya. Saat mengkonsumsi berita, seseorang akan memepertimbangkan aspek kebutuhan miliknya. konten-konten berita

yang menunjang aktivitas keseharian dan informasi seputar kejadian maupun gaya hidup terkini. Latar belakang pendidikan dan profesi ternyata juga mempengaruhi pemahaman dalam konsep berita insidental serta keputusan seseorang untuk mengkonsumsi berita tersebut. Narasumber dengan pendidikan tinggi dan memiliki pekerjaan yang selalu menggunakan perangkat seperti $P C$ atau laptop dan smartphone ternyata miliki kesadaran dan kewaspadaan yang lebih tinggi dibandingkan yang narasumber yang bekerja tanpa menggunakan laptop dan smartphone.

\section{Konten Berita yang Diminati}

Seseorang menggunakan media sosial salah satunya adalah kondisi psikologis sebagai sebuah hasil dari cara memandang, menerjemahkan, dan mencari jawaban dari sebuah masalah yang timbul di kehidupan seseorang. Seperti yang didapatkan dari hasil wawancara terhadap 20 orang dewasa yang telah bekerja. Sebagian besar narasumber membuka sosial media untuk mendapatkan hiburan atau untuk merasa lebih santai setelah seharian tenaga dan pikirannya terkuras di tempat kerja. Media sosial tidak hanya berperan sebagai tempat mengakses informasi tetapi juga sebagai tempat melepaskan stress. Mereka bermain game online, memutar lagu-lagu kesukaan atau lagu kenangan, mengamati mode terbaru, atau membuka 
kanal tayangan olahraga. Berkaitan dengan hobi, mereka menggunakan gawai untuk mengakses berita seputar olah raga hingga bercocok tanam. Dari hasil wawancara pada 20 narasumber didapatkan beberapa topik berita yang disukai antara lain:

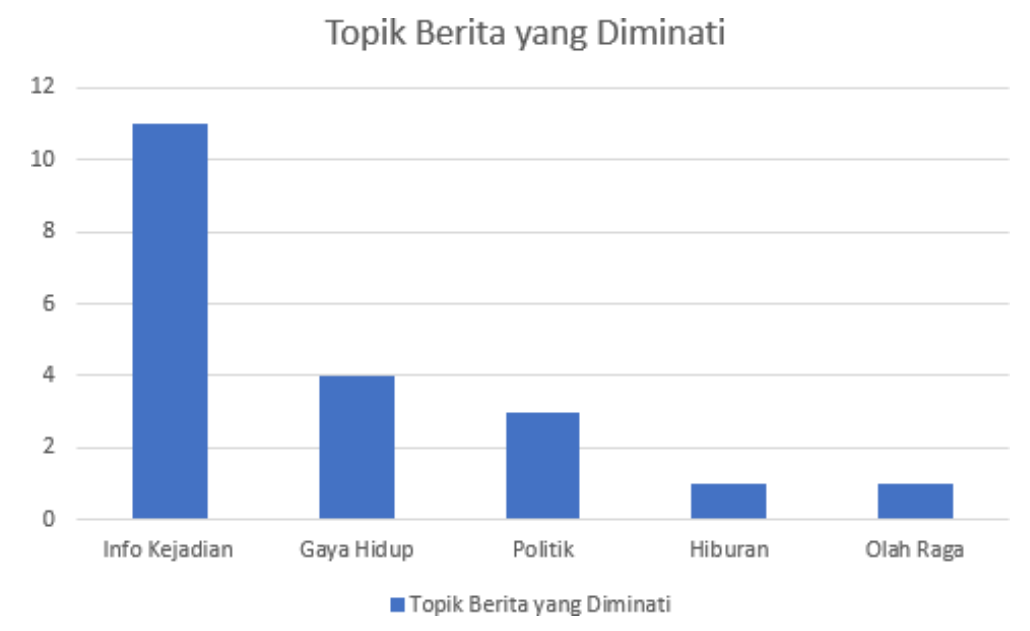

Gambar 1. Angka Peminat Topik Berita

Berbicara tentang media sosial sebagai tempat mencari informasi, orang dewasa cenderung berbeda dalam pemilihan topik informasi atau berita yang mereka pilih. Orang dewasa cenderung memilih topik info kejadian di suatu daerah, politik, dan gaya hidup. Dari 20 orang responden, sebanyak 11 orang memilih konten berita info kejadian terkini, 4 orang memilih konten gaya hidup, 3 orang memilih konten politik, sedangkan untuk konten hiburan dan olah raga masing-masing hanya 1 orang. Dapat dilihat bahwa faktor usia memengaruhi bagaimana pemilihan konten berita yang dikonsumsi. Konten yang dipilih disesuaikan tidak hanya pada seputar minat mereka namun pada segi kebutuhan mereka. dengan kata lain sesungguhnya latar belakang seseorang juga mempengaruhi pemilihan topik berita yang dikonsumsi.

Ketiga narasumber yang bekerja sebagai ojek online, 2 wiraswasta dan 6 orang guru yang tinggal jauh dari lokasi bekerja memilih konten info kejadian terkini karena ketika mereka akan pergi bekerja, mereka terlebih dahulu mencari berita atau informasi terkini terkait daerah itu untuk berjaga-jaga jika ada situasi yang berbahaya atau harus dihindari di jalan. Mereka tidak ingin terjebak dalam kemacetan, banjir, dan kendala perjalanan lainnya. Urutan kedua adalah konten gaya hidup. Orang dewasa yang sebagian besar telah hidup mandiri, mapan, berkecukupan, dan terpisah dari keluarganya sering mengakses konten berita tentang gaya hidup. seperti yang dilakukan oleh seorang pegawai bank, seorang guru dan 2 orang wiraswasta. Mereka berselancar di medsos untuk mencari informasi terkait tren terkini dari sebuah tren berbusana. Mereka juga mengakses berita tentang tren gaya hidup sehat dan mencoba menerapkannya dalam kehidupan sehari-hari. Untuk konten berita selanjutnya adalah konten politik. Konten ini diminati oleh 3 narasumber yang kebetulan bekerja di sektor pendidikan, dimana isu tentang politik dapat memiliki keterkaitan dengan pekerjaan mereka. Kebijakan atau regulasi baru dari hulu ke hilir mereka simak untuk ancang-ancang melakukan tindak lanjut. Maka dari itu, mereka mengikuti perkembangan isu politik terkini lewat media 
sosial. Terakhir adalah konten hiburan dan olah raga. Konten hiburan dipilih oleh 1 orang pegawai bank dan konten olah raga dipilih oleh seseorang yang berkerja sebagai tenaga medis.

Konten hiburan disini yang merupakan salah satu fungsi utama media sosial setelah fungsi informasi sebagai peringkat terakhir jika penggunanya adalah orang dewasa. Orang dewasa cenderung menggunakan medsos untuk mencari informasi yang bermanfaat dan krusial bagi kehidupan mereka. Sedangkan penggunaan medsos bagi orang dewasa hanya pada waktu luang atau disela-sela pekerjaan mereka. Mereka yang bekerja di depan layar setiap harinya akan memilih untuk beristirahat dan bermain dengan anak setelah pulang ke rumah daripada bermain media sosial. Dalam segi konten hiburan, media sosial saat ini banyak berisikan konten yang dianggap lebih pantas untuk anak muda dan kekanak-kanakan. Dengan kata lain orang dewasa jarang menggunakan medsos untuk mengakses konten hiburan dikarenakan kurangnya minat dan keterbatasan waktu yang dimiliki.

\section{Pemahaman Konsep Berita Insidental}

Berita insidental muncul sebagai hasil dari kinerja sistem algoritma yang ada pada media sosial. Berita insidental sekonyong-konyong menyusup dan mencuri perhatian pengguna medsos. Ini bukan kebetulan tetapi kerja sebuah sistem dari aplikasi operator. Sistem ini memungkinkan pengguna mendapatkan konten yang sesuai dengan rekam jejak penelusuran internet mereka hingga perilaku orang-orang yang mereka ikuti di medsos. Yang menjadi ironis adalah dari dua puluh orang narasumber hanya dua orang yang menyadari bahwa berita insidental yang muncul adalah hasil dari rekam jejak digital mereka. "Biasanya karena habis buka berita di google atau mencari berita di search ig, informasi berita tersebut sesuai sih". Sisanya lebih merasa tidak perduli akan asal usul dari munculnya berita insidental tersebut. Selain muncul dari rekam jejak digital pemilik akun tersebut, ternyata berasal dari orang-orang berpengaruh yang pengguna ikuti di medsos. Orang-orang berpengaruh ini yang dinamakan sebagai opinion leader. Peran dari opinion leader disini adalah untuk membagikan konten berita yang mereka minati kepada pengikut akun mereka, tidak hanya berbagi saja, ketika opinion leader memberikan komentar atau menyukai suatu postingan maka akan muncul juga dalam fitur pencarian di Instagram. Opinion leader adalah orang yang memiliki eksistensi tinggi di medsos. Data yang didapatkan peneliti menunjukkan bahwa sebanyak 16 orang atau lebih dari narasumber mendapatkan berita insidental dari teman yang mereka ikuti di Instagram atau opinion leader. Fakta ini juga menjawab pertanyaan sebelumnya tentang apakah berita insidental yang muncul sesuai dengan peminatan mereka. 5 orang menjawab tidak sesuai karena mereka mendapatkannya dari teman mereka, 8 orang menjawab kadangkadang karena mereka adalah tipe orang yang mengikuti tren sehingga kadang jika berita yang muncul sudah lewat masanya mereka jadi tidak tertarik lagi, sisanya 7 orang menjawab sesuai dengan minat, karena teman-teman yang mereka ikuti memiliki kesamaan pandangan dan minat.

Fenomena opinion leader dan penggunaan sosial media sebagai alat untuk menyebarkan berita insidental yang langsung terhubung dengan situs asli pembuat konten berita ini dapat dikaji menggunakan teori aliran dua tahap. Seperti yang didapatkan dari hasil wawancara bahwa sebagian besar narasumber mendapatkan rekomendasi berita atau berita insidental dari teman yang mereka ikuti. Ketika teman atau opinion leader yang mereka ikuti 
menyukai atau mengomentari suatu postingan maka akan muncul di fitur pencarian. Serta proses pernyebaran berita di fitur story/snapgram dan message juga menjadi salah satu contoh proses two step flow dalam distribusi konten berita. Pengguna mendapatkan berita insidental yang mereka minati atau dibagikan oleh opinion leader kemudian mengklik atau swipe-up pada berita insidental tersebut dan dapat secara otomatis terhubung ke situs asli pembuat konten berita. Dalam mendapatkan berita, pengguna membutuhkan perantara sosial media dan opinion leader untuk mencapai sumber utama berita. Dua faktor itulah yang menghadapkan pengguna medsos pada berita insidental. Di era digitalisasi ini kemunculan berita yang sekonyong-konyong sudah menjadi kelaziman. Konsumen berita atau pengguna medsos dengan duduk manis sudah mendapatkan sajian berselera tanpa harus melakukan proses pencarian sendiri ke situs website berita.

Media sosial kini memudahkan penggunanya dalam menerima dan menyebarkan informasi. Namun demikian bagi pengguna sosial media dari kalangan orang dewasa, mereka cenderung lebih selektif dalam memilih, menerima, dan menyebarkan berita. Berdasarkan hasil wawancara, didapatkan fakta bahwa orang dewasa lebih kritis dalam mengkonsumsi berita online di sosial media begitupun untuk melakukan sharing di sosmed. Sebanyak 11 orang mengatakan pernah menyebarkan berita dari alamat website pembuat konten berita seperti Tribun, BBC, dan portal berita online sejenisnya, hanya setelah mereka mengecek situs resmi asal berita tersebut. Sisanya sebanyak 9 orang mengaku tidak menyebarkan berita karena takut berita tersebut adalah berita bohong atau hoax. Dapat kita lihat bahwa orang dewasa yang secara umum telah berpikir matang serta berpengalaman dalam segi edukasi dan literasi media akan lebih berhati-hati dan waspada terhadap hoax dalam menggunakan media sosial. Sebanyak 15 orang narasumber mengaku selalu mengunjungi situs atau website asli pembuat konten berita untuk menelusuri kebenaran berita yang muncul tersebut. Sifat kehati-hatian membuat mereka selektif dalam mengonsumsi dan menyebarluaskan berita kepada kerabat, teman dekat, dan khalayak.

\section{Keputusan Konsumsi Berita Insidental}

Hasil dari wawancara pada penelitian ini terkait dengan keputusan konsumsi berita incidental di sosial media dapat dilihat dengan menggunakan grafik sebagai berikut: 


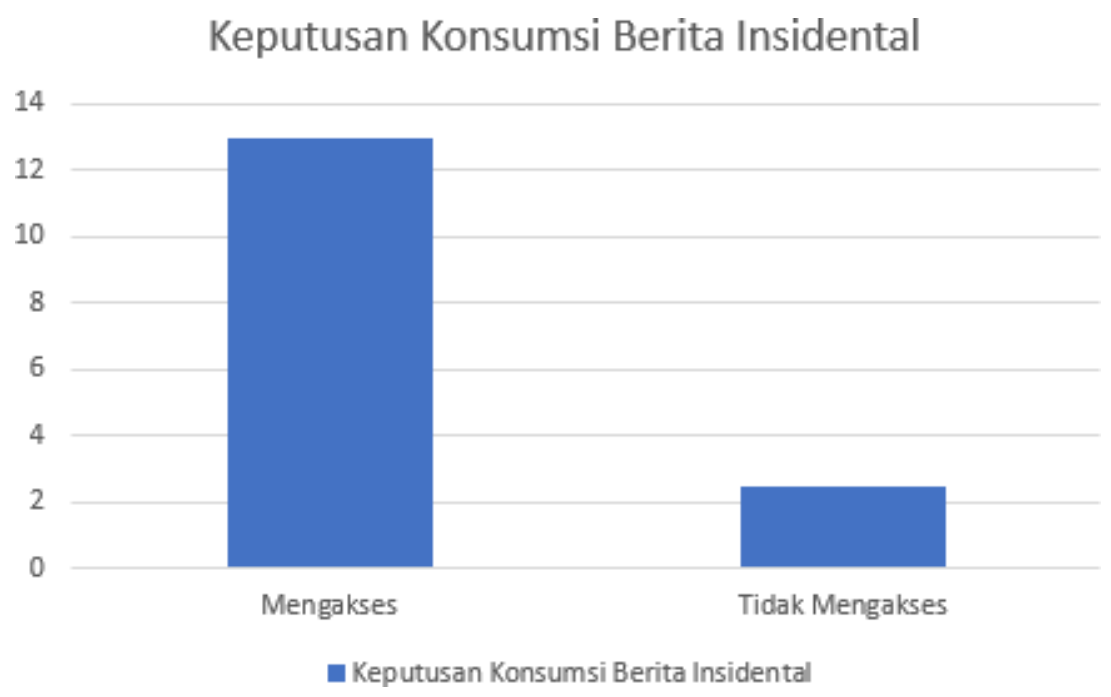

Gambar 2. Angka Keputusan Mengkonsumsi Berita Insidental

Kemunculan berita insidental bagi sebagian orang merupakan gangguan karena jika berita tersebut muncul dari opinion leader terkadang kurang sesuai dengan minat dan terkesan sebagai spam atau sampah timeline, bahkan informasi yang didapatkan dapat dianggap berlebihan. hasil dari wawancara menunjukan bahwa beberapa orang melihat kemunculan berita insidental sebagai ganguan yang cukup merepotkan. Kelebihan atau banjir informasi ternyata tidak selalu berujung baik, bisa malah menjadikan timbulnya kecemasan tersendiri bagi beberapa orang.

"Mengganggu, karena kadang jadi beban. Apalagi pas rame-ramenya Covid-19, jadi resah. Makanya sekarang selalu di skip kalo ada berita-berita begitu”

Kemunculan click bait disaat kita tengah asik mengakses suatu konten memang oleh beberap orang dianggap seperti spam dan kemunculan ini sulit bahkan tidak dapat kita kendalikan karena merupakan olahan dari sistem algoritma di media sosial. Tidak jarang kita tidak sengaja menekan click bait tersebut dan kesulitan untuk kembali ke halaman awal yang kita akses. Apalagi jika halaman sumber dari berita insidental tersebut bukan sumber yang terpercaya dan dapat malah menambah sampah digital untuk perangkat kita. Namun ternyata bagi sebagian besar narasumber, yaitu sebanyak 13 orang, mereka beranggapan bahwa berita insidental yang muncul dapat membantu mereka untuk lebih cepat mencapai situs utama pembuat berita dan secara tidak langsung memenuhi asupan informasi yang mereka minati dan butuhkan sewaktu-waktu. dimaksud"

"Untuk pop-up lebih memudahkan karena sekali klik langsung muncul berita yang

Pernyataan diatas adalah contoh tanggapan progresif dari narasumber yang merasakan dirinya sangat terbantu dalam proses pencarian berita. Secara tidak langsung berita insidental yang muncul sudah pasti memiliki hubungan dengan minat maupun konten yang paling sering dicari sehingga suguhan jalan pintas tanpa bersusah payah mengetik apa kata kunci informasi yang ingin diketahui. Hasil temuan ini mendukung penelitian terdahulu milik Suciati dan Fauziah tentang pergeseran pola perilaku dalam pencarian berita dan informasi. Masyarakat yang dulu harus bersusah payah mencari informasi atau berita terbaru dan lumayan memakan 
waktu, kini dapat mengaksesnya dengan sekali klik. Bahkan, mereka dapat mengaksesnya secara tidak sengaja berkat pop-up berita itu muncul saat tengah mengakses konten lainnya.

"Terkadang saat bermedia sosial kita lupa dengan berita terkini jadi pop-up berita terkini tersebut bisa membantu"

Pop-up berita tersebut bisa saja menjadi bahan pembicaraan tatkala bercengkerama bersama keluarga. Bisa jadi munculnya berita insidental yang mengubah agenda acara jika kontennya berkait langsung dengan objek sasaran. Tidak hanya dapat menambah wawasan lebih mendalam namun juga bermanfaat jika terlewatkan hal penting dari konten tersebut dapat terus mengikuti perkembangannya. Kemudahan dalam mengakses sumber berita asli ini yang membuat sebagian besar narasumber penelitian memilih untuk tetap mengkonsumsi berita insidental.

\section{KESIMPULAN}

Berdasarkan hasil dan pembahasan di atas dapat disimpulkan bahwa keberadaan atau kemunculan berita insidental pada akun media sosial khususnya Instagram telah disadari oleh para penggunannya. Mereka atau hampir seluruh penggunanya pernah menemukan berita insidental saat menggunakan Instagram. Namun demikian adanya kesadaran yang masih rendah mendorong pengguna medsos beranggapan bahwa berita insidental tersebut adalah hasil dari sistem algoritma di Instagram. Mereka berasumsi sistem tersebut mengolah rekam jejak penelusuran di internet serta peran dari opinion leader. Maka dari itu sebagian besar pengguna lebih memilih untuk tidak peduli dengan fakta bahwa jika menyukai, membagikan atau menelusuri suatu postingan dapat merujuk pada munculnya konten serupa di fitur penelusuran akun Instagram mereka. Persepsi itu berbeda dengan pengguna medsos yang memiliki kesadaran lebih tinggi dan pemikiran yang logis. Mereka bersikap apresiatif dengan berita insidental karena konten pada berita insidental merupakan hasil dari sistem algoritma. Atas dasar alur pikir yang sistematis itu membenarkan bahwa konten berita insidental sesuai dengan minat pengguna dan dapat menjadi penggiring untuk mengunjungi situs asli pembuat berita.

Hasil juga menunjukkan bahwa tingkat usia atau generasi dan latar belakang pekerjaan juga memengaruhi keputusan untuk mengkonsumsi berita insidental. Orang dewasa yang telah bekerja dengan rentang usia 23-25 tahun, lebih memilih konten berita yang memiliki fungsi informasi untuk memenuhi kebutuhan hidup mereka daripada konten-konten hiburan. Hal ini dipengaruhi oleh prioritas hidup maupun pekerjaan dan keterbatasan waktu luang yang dimiliki oleh orang dewasa. Orang dewasa juga akan menelusuri sumber asli berita ketika mendapatkan suatu berita. Hal ini dilakukan untuk membuktikan bahwa berita tersebut bukanlah berita bohong. Mereka menelusur dan mengkroscek apakah berita tersebut memang berasal dari sumber yang terpercaya atau tidak.

Berita Insidental memiliki beberapa manfaat bagi pengguna media sosial. Pertama, menjadikan proses pencarian berita lebih efektif efisien. Orang-orang yang kritis dalam menerima informasi di media sosial, mereka dapat langsung menelusuri sumber berita dengan sekali klik saja. Kedua, memberikan keuntungan bagi pihak perusahaan media, pemilik portal internet maupun pihak media sosial sendiri. Media sosial kini menjadi ladang yang subur untuk menanamkan berita insidental yang menggiring orang-orang mengunjungi situs website 
mereka. Dari setiap kunjungan dapat dihitung secara material. Memanfaatkan kemudahan dalam mengakses berita melalui berita insidental memang sudah terbukti efisien bagi beberapa kalangan. Namun sebagian masyarakat saat ini hanya sekedar melihat dari segi manfaatnya saja. Teori kemunculan berita insidental yang menggunakan rekam jejak digital pengguna untuk memberikan informasi sekaligus menggiring ke sumber asli berita, dua hal ini masih menimbulkan pertanyaan dan dapat digunakan sebagai inspirasi penelitian lebih lanjut.

\section{REFERENSI}

Ahmed, W., \& Lugovic, S. (2019). Social media analytics: analysis and visualisation of news diffusion using NodeXL. Online Information Review, 43(1), 149-160. https://doi.org/10.1108/OIR-03-2018-0093

Alam, A., \& Kim, K. S. (2021). Mobile News Engagement in a South Asian Context : Roles of Demographics, Motivations, and News Type Preferences in News Exposure and Participation in, 17(2). https://doi.org/https://doi.org/10.5392/IJoC.2021.17.2.048

Ali, K. (2019). Viruses Going Viral: Impact of Fear-Arousing Sensationalist Social Media Messages on User Engagement. Sage Journal, 41(3), 314-338. https://doi.org/https://doi.org/10.1177/1075547019846124

Alsh, I., Holton, J. A., Bailyn, L., Fernandez, Walter, Levina, Natalia and Glaser, B. (2015). What Grounded Theory Is...A Critically Reflective Conversation Among Scholars. Sage Journal, 18(4), 581-599. https://doi.org/https://doi.org/10.1177/1094428114565028

Anspach, N. M. (2017). The New Personal Influence: How Our Facebook Friends Influence the News We Read. Political Communication, 34(4), 590-606. https://doi.org/https://doi.org/10.1080/10584609.2017.1316329

Asosiasi Penyelenggara Jasa Internet Indonesia. 2016. Survey Internet APJII 2016. Official Website APJII. https://www.apjii.or.id/content/read/39/264/Survei-Internet-APJII-2016

Bergström, A., \& Jervelycke Belfrage, M. (2018). News in Social Media: Incidental consumption and the role of opinion leaders. Digital Journalism, 6(5), 583-598. https://doi.org/10.1080/21670811.2018.1423625

Boczkowski, P. J., Matassi, M., \& Mitchelstein, E. (2018). How young users deal with multiple platforms: The role of meaning-making in social media repertoires. Journal of Computer-Mediated Communication, 23(5), 245-259. https://doi.org/10.1093/jcmc/zmy012

Bode, L. (2016). Political News in the News Feed: Learning Politics from Social Media. Mass Communication and Society, 19(1), 24-48. https://doi.org/10.1080/15205436.2015.1045149

Domingo, D., Masip, P., \& Costera Meijer, I. (2015). Tracing digital news networks: Towards an integrated framework of the dynamics of news production, circulation and use. Digital Journalism, 3(1), 53-67. https://doi.org/10.1080/21670811.2014.927996 
Heiss, R., \& Matthes, J. (2019). Does incidental exposure on social media equalize or reinforce participatory gaps? Evidence from a panel study. New Media and Society, 21(11-12), 2463-2482. https://doi.org/10.1177/1461444819850755

Hermida, A. (2010). Twittering the news: The emergence of ambient journalism. Journalism Practice, 4(3), 297-308. https://doi.org/10.1080/17512781003640703

Hermida, A., Fletcher, F., Korell, D., \& Logan, D. (2012). SHARE, LIKE, RECOMMEND: Decoding the social media news consumer. Journalism Studies, 13(5-6), 815-824. https://doi.org/10.1080/1461670X.2012.664430

Jihyang Choi. (2016). Why do people use news differently on SNSs? An investigation of the role of motivations, media repertoires, and technology cluster on citizens' news-related activities. Computers in Human Behavior, 54(C), 249-256. https://doi.org/https://doi.org/10.1016/j.chb.2015.08.006

Kaiser, J., Keller, T. R., \& Kleinen-von Königslöw, K. (2021). Incidental News Exposure on Facebook as a Social Experience: The Influence of Recommender and Media Cues on News Selection. Communication Research, 48(1), 77-99. https://doi.org/10.1177/0093650218803529

Karlsen, R. (2015). Followers are opinion leaders: The role of people in the flow of political communication on and beyond social networking sites. Sage Journal, 30(3), 301-318. https://doi.org/https://doi.org/10.1177/0267323115577305

Karnowski, Veronika; Kümpel, Anna Sophie; Leonhard, Larissa; Leiner, D. (2017). From incidental news exposure to news engagement. How perceptions of the news post and news usage patterns influence engagement with news articles encountered on Facebook. Computers in Human Behavior, 7, 42-50. https://doi.org/DOI: 10.1016/j.chb.2017.06.041

Kjerstin Thorson. (2016). Curated Flows: A Framework for Mapping Media Exposure in the Digital Age. Communication Theory, 26(3), 309-328. https://doi.org/https://doi.org/10.1111/comt.12087

Kormelink, T. G., \& Meijer, I. C. (2018). What clicks actually mean: Exploring digital news user practices. Journalism, 19(5), 668-683. https://doi.org/10.1177/1464884916688290

Lariscy, R.W., Tinkham, S.F. and Sweetser, K. . (2011). Kids These Days: Examining Differences in Political Uses and Gratifications, Internet Political Participation, Political Information Efficacy, and Cynicism on the Basis of Age. Sage Journal, 55(6), 749-764. https://doi.org/https://doi.org/10.1177/0002764211398091

Puspita, R., \& Suciati, T. N. (2020). Mobile Phone dan Media Sosial: Penggunaan dan Tantangannya pada Jurnalisme Online Indonesia. Ekspresi Dan Persepsi : Jurnal Ilmu Komunikasi, 3(2), 132. https://doi.org/10.33822/jep.v3i2.1781

Rusadi, U. (2014). Konsumsi Berita Lintas Media Massa Konvensional Dan Internet. Jurnal Penelitian Dan Pengembangan Komunikasi Dan Informatika, 4(3), 173-187. 
Rusadi, U. (2014). Makna Dan Model Komunikasi Pembangunan. Jurnal Studi Komunikasi Dan Media, 18(1), 89. https://doi.org/10.31445/jskm.2014.180105

Setiadi, A. (2014). Pemanfaatan media sosial untuk efektifitas komunikasi. Jurnal Ilmiah Matrik, 16(1). Retrieved from https://ejournal.bsi.ac.id/ejurnal/index.php/cakrawala/article/view/1283/1055

Shelley Boulianne. (2018). Mini-publics and Public Opinion: Two Survey-Based Experiments. Sage Journal, 66(1), 119-136. https://doi.org/https://doi.org/10.1177/0032321717723507

Suciati, T. N., \& Fauziah, N. (2020). Layak Berita Ke Layak Jual: Nilai Berita Jurnalisme Online Indonesia Di Era Attention Economy. Jurnal Riset Komunikasi, 3(1), 51-69. https://doi.org/10.24329/jurkom.v3i1.105

Sveningsson, M. (2015). "It's Only a Pastime, Really": Young People's Experiences of Social Media as a Source of News about Public Affairs. Social Media and Society, 1(2). https://doi.org/10.1177/2056305115604855

Turcotte, J., York, C., Irving, J., Scholl, R. M., \& Pingree, R. J. (2015). News Recommendations from Social Media Opinion Leaders: Effects on Media Trust and Information Seeking. Journal of Computer-Mediated Communication, 20(5), 520-535. https://doi.org/10.1111/jcc4.12127

Valeriani, A., \& Vaccari, C. (2016). Accidental exposure to politics on social media as online participation equalizer in Germany, Italy, and the United Kingdom. New Media and Society, 18(9), 1857-1874. https://doi.org/10.1177/1461444815616223

Walsh, I., Holton, J. A., Bailyn, L., Fernandez, W., Levina, N., \& Glaser, B. (2015). What Grounded Theory Is...A Critically Reflective Conversation Among Scholars. Organizational Research Methods, 18(4), 581-599. https://doi.org/10.1177/1094428114565028

Whiting, A., \& Williams, D. (2013). Why people use social media: a uses and gratifications approach. Qualitative Market Research: An International Journal, 16(4), 362-369. https://doi.org/10.1108/QMR-06-2013-0041

Yamamoto, M., \& Morey, A. C. (2019). Incidental News Exposure on Social Media: A Campaign Communication Mediation Approach. Social Media + Society, 5(2), 205630511984361. https://doi.org/10.1177/2056305119843619

Yoonmo Sang. (2014). Exploring political discussions by Korean twitter users: A look at opinion leadership and homophily phenomenon. Aslib Journal of Information Management, 66(6), 2050-3806. https://doi.org/DOI 10.1108/AJIM-11-2012-0089 